\title{
Distribution of heavy metals in soils of the Yellow River Delta: concentrations in different soil horizons and source identification
}

\author{
Yuan Li • Haibo Zhang • Xiaobing Chen • Chen Tu • \\ Yongming Luo $\cdot$ Peter Christie
}

Received: 11 November 2013 / Accepted: 24 January 2014 / Published online: 18 February 2014

(C) Springer-Verlag Berlin Heidelberg 2014

\begin{abstract}
Purpose The Yellow River Delta, an active land-ocean interaction area, will develop into a large eco-economic region in East China during the coming decade. It is necessary to assess the geochemical features of heavy metals in the soils. The objectives of this research were to evaluate the concentrations and distribution of heavy metals $(\mathrm{Cr}, \mathrm{Ni}, \mathrm{Cu}, \mathrm{Zn}, \mathrm{Pb}$, and $\mathrm{Cd})$ in soil profiles of the area and to identify their sources.

Materials and methods Horizon samples were collected based on pedogenic features from bottom to top in each profile to a depth of $120 \mathrm{~cm}$ and a total of 92 samples were collected. The sampling sites were grouped into four lines from inland to coastal area with three land use types (cotton field, cereal field, and wetland). The concentrations of $\mathrm{Cr}, \mathrm{Ni}, \mathrm{Cu}, \mathrm{Zn}, \mathrm{Pb}$, and $\mathrm{Cd}$ were measured by inductively coupled plasma-mass spectrometry. Iron oxide fractions in the soil were extracted by oxalate-oxalic acid and dithionite-citrate-bicarbonate. X-ray diffraction (XRD) was used to determine the mineral composition of the soils. Multivariate statistical analysis and historical data were employed to identify the possible sources of these heavy metals.
\end{abstract}

Responsible editor: Willie Peijnenburg

$\mathrm{Y}$. Li $\cdot$ H. Zhang $\cdot$ X. Chen $\cdot$ C. Tu $\cdot$ Y. Luo $(\triangle)$

Key Laboratory of Coastal Zone Environmental Processes and Ecological Remediation, Yantai Institute of Coastal Zone Research, Chinese Academy of Sciences, Yantai, Shandong 264003, People's Republic of China

e-mail:ymluo@yic.ac.cn

P. Christie

Agri-Food and Biosciences Institute, Newforge Lane, Belfast BT9

5PX, UK

Y. Li • Y. Luo

Chinese Academy of Sciences University, Beijing 100039, People's Republic of China
Results and discussion The mean concentrations of heavy metals were elevated along the Yellow River region and in the southern part of the delta; however, they were generally lower than the Chinese guideline values. As for the depth distribution of heavy metals in soil profiles, the maximum values of $\mathrm{Cr}, \mathrm{Ni}, \mathrm{Cu}, \mathrm{Zn}$, and $\mathrm{Cd}$ in middle horizon of cotton field were almost twice than those in surface horizon. The iron oxides and XRD analysis indicated that the trace elements accumulation appeared to be related with the contents of crystalline iron oxide and layer silicates. Historical data from suspended sediments of the Yellow River and principal component analysis (PCA) implied that most of the metals $(\mathrm{Cr}, \mathrm{Ni}$, $\mathrm{Cu}$, and $\mathrm{Zn}$ ) were sourced from natural alluviation and sedimentation.

Conclusions The Yellow River Delta soils were slightly polluted by heavy metals the Yellow River Delta. The special pedogenic horizon characterized by higher iron oxides and layered silicates minerals in the middle and lower part of the soil profile was found with heavy metals enrichment, which required to be studied further. Suspended sediments transported by the Yellow River were suggested to be one of the major sources for the heavy metals accumulation in the basal soils of this region.

Keywords Heavy metals · Metal accumulation · Soil profiles $\cdot$ Yellow River Delta

\section{Introduction}

Soil contamination by heavy metals has aroused widespread concern because of its potential threat to public health and adverse effects on the environment. An elevated level of toxic metals in the coastal soils has drawn considerable concerns under the rapid industrialization and intensification of agriculture in the coastal regions of China (Zhang et al. 2007). High 
contents of toxic metals, like $\mathrm{Cd}, \mathrm{Cr}$, and $\mathrm{Pb}$ might pose a great threat to human health by accumulation in the terrestrial plants and consumption subsequently (Cui et al. 2011). Meanwhile, the toxic metals would also be introduced into estuarine and coastal environment continually by river water and sediments transportation and affected the surrounding marine ecosystem (Förstner et al. 2004, Laing et al. 2009). During the past few decades, environmental pollution caused by heavy metals has been identified in several delta areas, such as in the Mekong river delta (Cenci and Martin 2004), the Pearl River delta (Bai et al. 2011a), the Niger delta (Olawoyin et al. 2012), and the Mississippi delta (Mielke et al. 2001). The soils were assumed to be a sink as well as a source of heavy metals in the coastal area of the delta region. The mobility of heavy metals could be influenced by soil properties, soil structure, and soil development. Ip et al. (2007) reported that the reduction of dissolved and particulate trace metals was enhanced in soils of Pearl River Estuary due to the presence of organic matter and divalent iron $(\mathrm{Fe})$ and clays. Heavy metals were not necessarily fixed permanently to soils, but they also took part in biogeochemical cycles; therefore, assessment of their distribution in soils was a key issue in many environmental studies (Tessier and Campbell 1987).

The Yellow River Delta (YERD) is one of the most active regions of land-ocean interaction and is an overwintering and breeding site for migrating birds in inland of northeast Asia and the western Pacific Rim (Yue et al. 2003). However, nowadays, the delta today was under huge pressures both from both industrial and agricultural development. It has developed into a major region in the North China for largescale agriculture and fish farming and petroleum refining during the past decades (Fang et al. 2005). Previous studies have found elevated contents of heavy metals in soils and sediments of the Yellow River Delta from both anthropogenic and geologic sources. Bai et al. (2012) showed that As and Cd were at moderately or strongly polluted in the YERD wetland soils and this might be attributed to the flow-sediment regulation regime. Similar heavy metal contamination levels were observed in the tidal ditch of the Yellow River Estuary where $\mathrm{Cr}, \mathrm{Cu}$, and $\mathrm{Ni}$ originate mainly from the parent rocks and $\mathrm{Pb}$ possibly from tidal seawater and oil field pollution (Bai et al. 2011b). However, these studies focused mainly on the wetland of the YERD and little information is available on the biogeochemical variability of soil heavy metals across the whole region. Moreover, most of the available information on the distribution of heavy metals has been determined in topsoil samples. Little is known about the movement of heavy metals throughout the soil profile. Therefore, it is necessary to identify the concentrations, distributions, and possible sources of the heavy metals in soil profiles of the agricultural lands and wetlands in order to propose a systematic coastal soil management for this region.
The YERD has the fastest rate of land growth in the world due to very high mud content in the river flow and sediments around the river mouth. The results were expected to provide some insight on the accumulation and origins of metals in the alluvial soils. The primary objectives of this study were: (1) to assess the concentrations of heavy metals $(\mathrm{Cd}, \mathrm{Cr}, \mathrm{Cu}, \mathrm{Ni}, \mathrm{Pb}$, and $\mathrm{Zn}$ ) in the soil profiles in YERD, (2) to examine the binding of heavy metals to the soil fractions, and (3) to identify the sources of the metals using multivariate analysis and historical data.

\section{Materials and methods}

\subsection{Study area and sample collection}

The Yellow River Delta, geographically spanning $38^{\circ} 08^{\prime}-$ $36^{\circ} 58^{\prime} \mathrm{N}$ and $118^{\circ} 09^{\prime}-119^{\circ} 05^{\prime} \mathrm{E}$ (Fig. 1), is located in northern Shandong province, north China. It is situated on the south edge of the Bohai Sea and has a temperate, semihumid continental monsoon climate. The average annual temperature is $11.7-12.6{ }^{\circ} \mathrm{C}$. The average annual precipitation is $530-630 \mathrm{~mm}$ of which $70 \%$ is rainfall occurring during summer (May-July) and the average annual evaporation is $1,900-2,400 \mathrm{~mm}$ (Yu et al. 2011). The current course of the Yellow River has resulted from an artificial change from the Diaokou course to the Qingshuigou course in 1976, followed by a shift towards the north bank of the Qingshuigou course in 1996.

The sampling sites were grouped into four lines according to local geographic characteristics. Line A (A1-A6) was along the Yellow River and ended in the estuarine wetland. Line B (B1-B6 and A1) extended to the north region (Diaokou course) from the south of the Yellow River. Soil samples form line C $(\mathrm{C} 1-\mathrm{C} 4$ and A3) were collected from the south to north part of the study area. Four samples along line D (D1-D4) were collected along the Laizhou Bay. The general layout was sampling from the inland region to the coast, corresponding to densely populated and sparsely populated areas.

Horizon samples were collected based on pedogenic features from bottom to top in each soil profile, and a total of 92 samples were collected. For the convenience of statistical analysis, four to six horizons of each soil profile were combined into four horizons comprising (1) the surface soil horizon $(0-20 \mathrm{~cm})$, corresponding to a sandy loam horizon and ascribed to organomineral horizon; (2) subsurface horizon, a compacted sandy subplough horizon between 20 and $40 \mathrm{~cm}$ in depth; (3) middle horizon (40-70 cm), a loamy clay and sequioxide accumulation layer; and (4) basal horizon $(70-120 \mathrm{~cm})$, the underlying sandy material, corresponding to the alluvial parent material. However, the soil sample could 
Fig. 1 Map showing location of sampling sites

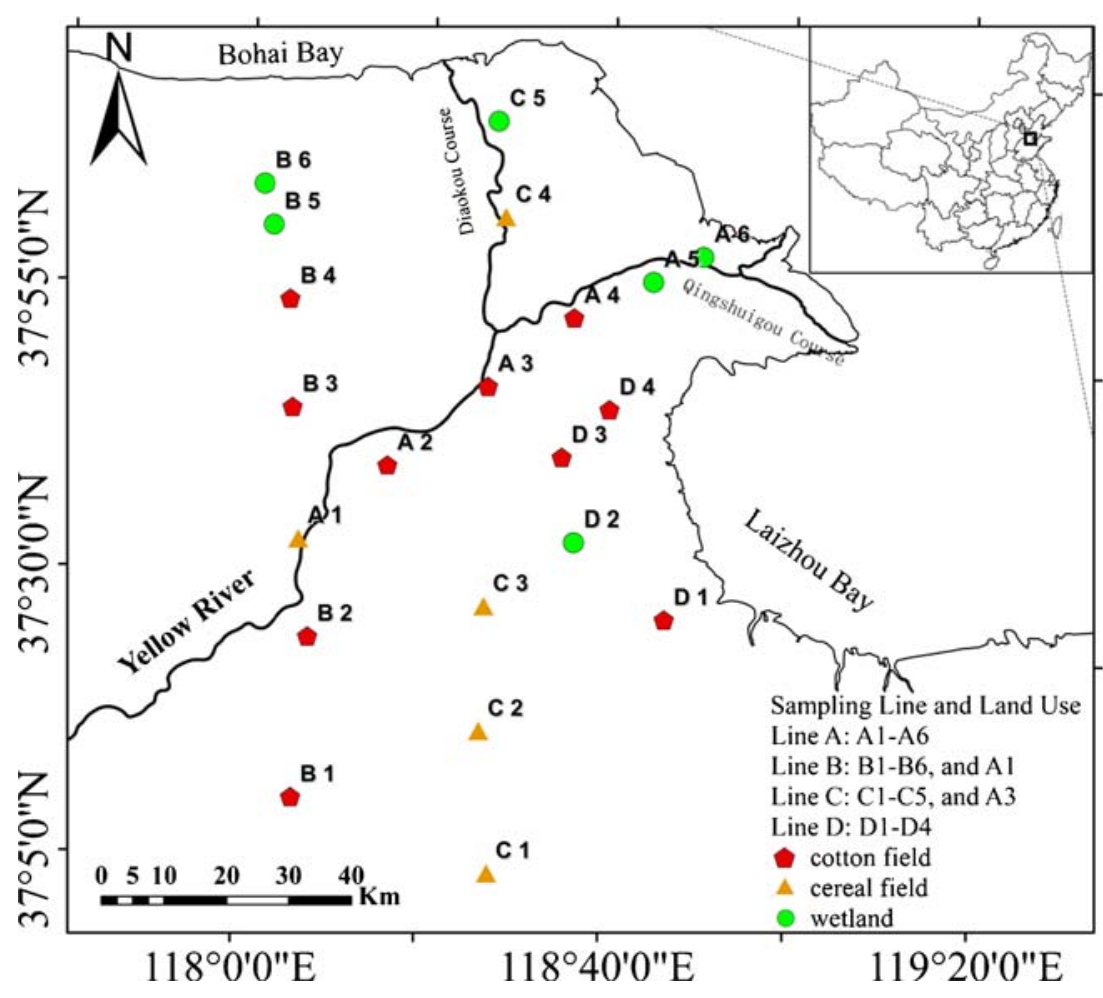

only be collected in a depth of $60 \mathrm{~cm}$ at some sampling sites due to the presence of groundwater. All the samples were collected using a clean stainless steel spade and placed in a cloth bag to prevent the growth of mildew and then transferred to the laboratory. The soil samples were air-dried and sieved through a 2-mm nylon sieve to remove large debris, stones, and pebbles for measurement of soil particle size, $\mathrm{pH}$, salinity, extractable metals content, and X-ray diffraction (XRD). Portions of the sieved samples were then grounded using a pestle and mortar until all particles passed a 0.149-mm nylon sieve for the analysis of heavy metals, soil organic matter, total soil $\mathrm{N}$, and $\mathrm{CaCO}_{3}$ content.

\subsection{Physicochemical analysis}

Soil organic matter (SOM) was measured using dichromate oxidation. Total soil N (TN) was determined on dried soil by dry combustion using an elemental analyzer (Vario MAX CNS, Elementar, Germany). Soil particle size was analyzed using a laser particle size analyzer (Marlvern Mastersizer 2000F, Malvern, UK). Soil pH was measured in a 1:2.5 soil-water suspension after stirring for $30 \mathrm{~min}$. Salinity was determined in the supernatant of 1:5 soil-water mixtures using the gravimetric method. The $\mathrm{CaCO}_{3}$ equivalent was determined by neutralization with $\mathrm{HCl}$ and back titration with $\mathrm{NaOH}$. Amorphous and free $\mathrm{Fe}$ fractions were measured in ammonium oxalate-oxalic acid and dithionite-citrate-bicarbonate (DCB) extracts, respectively. Extracted Fe and heavy metal concentrations were determined by inductively coupled plasma-optical emission spectrometry (ICP-OES, Optima 7000 DV, Perkin Elmer, USA). Soil analysis followed the procedures described by Lu (1999). Soil mineralogy was determined by X-ray diffraction (ULTIMA IV, Rigaku, Japan).

The total concentrations of metals were determined by inductively coupled plasma-mass spectrometry (ICP-MS, ELAN DRC II, Perkin Elmer, USA). About $0.10 \mathrm{~g}$ soil was digested with a 5:2:1 mixture of $\mathrm{HF}-\mathrm{HNO}_{3}-\mathrm{HClO}_{4}$ for $12 \mathrm{~h}$ at $180{ }^{\circ} \mathrm{C}$. In the analysis of metals, certified standard reference materials (GSS-2, GSS-6, GSS-7, and GSS-8 geochemical reference materials) from the National Research Center for Certified Reference Materials of China, were used in the digestion and analysis as part of the QA/QC protocol. Reagent blanks and analytical duplicates comprising $10 \%$ of the total samples were also used where appropriate to test the accuracy and precision of the analysis. The standard deviation remained within $5 \%$ for all of the metals determined.

\subsection{Statistical analysis}

Descriptive data analysis, comprising minimum value, mean value, maximum value, standard deviation, and coefficient of variation, was carried out with EXCEL 2010 and SPSS v. 20.0. In the principal component analysis (PCA), Varimax with Kaiser normalization was used as the rotation method in the analysis. 


\subsection{Index of geoaccumulation}

The geoaccumulation index $\left(I_{\text {geo }}\right)$ was utilized to assess the degree of contamination with soil heavy metals (Müller 1969), described as:

$I_{\text {geo }}=\log _{2}\left(\frac{C_{n}}{1.5 B_{n}}\right)$

where $C_{n}$ is the measured concentration of the element $n$ in a sample and $B_{n}$ is the natural background concentration of this element. These geochemical background values were obtained based on the mean values of environmental background concentrations of the $\mathrm{A}$ and $\mathrm{C}$ horizons of Shandong Province (CNEMC 1990). Each heavy metal may be classified as unpolluted $\left(I_{\text {geo }}<0\right)$, unpolluted to moderately polluted $\left(0<I_{\text {geo }}<1\right)$, moderately polluted $\left(1<I_{\text {geo }}<2\right)$, moderately to strongly polluted $\left(2<I_{\text {geo }}<3\right)$, strongly polluted $\left(3<I_{\text {geo }}<4\right)$, strongly to extremely polluted $\left(4<I_{\mathrm{geo}}<5\right)$, and extremely polluted $\left(I_{\mathrm{geo}}>5\right)$.

\section{Results and discussion}

\subsection{Soil properties in the studied area}

The mean values of soil properties in different sampling lines and types of land use are summarized in Table 1 . There were no significant differences in soil properties (with the exception of salinity) among the four sampling lines. The soils were sandy loam (61\% sand, $31 \%$ silt, and $8 \%$ clay), saline, and alkaline in nature ( $\mathrm{pH} 7.7-10.3)$, loosely arranged, light yellow or dark brown in color, and nutrientpoor. The calcium carbonate content was within the range of $7-10 \%$.

Table 1 Mean values of selected soil properties in the soil profiles at different sampling sites and surface horizon soils across all land use types

\begin{tabular}{cccccccc}
\hline & $\begin{array}{l}\mathrm{SOM} \\
\left.\left(\mathrm{g}^{-1}\right)^{-1}\right)\end{array}$ & $\begin{array}{l}\mathrm{TN} \\
\left(\mathrm{g} \cdot \mathrm{kg}^{-1}\right)\end{array}$ & $\begin{array}{l}\mathrm{Clay} \\
(\%)\end{array}$ & $\begin{array}{l}\mathrm{pH} \\
(2.5: 1)\end{array}$ & $\begin{array}{l}\text { Salinity } \\
\left(\mathrm{g} \cdot \mathrm{kg}^{-1}\right)\end{array}$ & $\begin{array}{l}\mathrm{CaCO}_{3} \\
(\%)\end{array}$ & $\mathrm{C}: \mathrm{N}$ \\
\hline \multicolumn{7}{c}{ Sampling sites (soil profile) } \\
Line A & 5.70 & 0.70 & 6.51 & 8.32 & 5.27 & 8.73 & 4.72 \\
Line B & 8.01 & 0.93 & 8.46 & 8.46 & 5.21 & 9.00 & 4.99 \\
Line C & 8.51 & 0.91 & 8.97 & 8.43 & 6.59 & 7.81 & 5.42 \\
Line D & 5.63 & 0.64 & 6.90 & 8.59 & 13.02 & 8.87 & 5.10 \\
Land use types (surface horizon) & & & & & \\
cotton & 10.69 & 1.04 & 7.32 & 8.26 & 6.58 & 8.66 & 5.96 \\
cereal & 14.70 & 1.40 & 8.03 & 8.32 & 4.55 & 7.57 & 6.09 \\
wetland & 15.17 & 1.16 & 2.98 & 8.23 & 10.22 & 9.17 & 7.58 \\
\hline
\end{tabular}

3.2 Assessment and spatial distribution of heavy metals

The descriptive statistics of the heavy metal concentrations are summarized in Table 2. Application of the $\mathrm{K}-\mathrm{S}$ test confirmed that the concentrations of $\mathrm{Cd}, \mathrm{Cr}, \mathrm{Cu}, \mathrm{Ni}, \mathrm{Pb}$, and $\mathrm{Zn}$ in the soils were normally distributed. The lower coefficients of variation (mostly below $50 \%$ ) of all metals suggest that the distribution of these elements in the soil horizons is relatively homogenous in the area, perhaps as a result of the delta being deposited layer by layer within sediments. There was no significant difference for mean concentrations of the heavy metals among three land use types $(p>0.05)$. However, the depth distributions of heavy metals in the soil profiles showed different tendencies. In cotton field soils, the maximum values of $\mathrm{Cr}, \mathrm{Ni}, \mathrm{Cu}, \mathrm{Zn}$, and $\mathrm{Cd}$ in the middle horizon were almost twice of those in the surface soils, indicating that some elements may accumulate in the subsoils. This might due to a red interlayer about $5-10 \mathrm{~cm}$ thick existed in the soil profiles of most cotton field sites. The relative enrichments of trace metals in the surface and subsurface horizon in cereal field soils implied the contributions of anthropogenic inputs. Comparatively, in wetland soils, high concentrations of $\mathrm{Cr}$, $\mathrm{Ni}, \mathrm{Cu}$, and $\mathrm{Zn}$ were observed in the basal soil horizon, suggesting the geogenic and pedogenic characteristics of most heavy metals in the wetland area.

The $I_{\text {geo }}$ of the heavy metals were categorized as shown in Fig. 2. The $\mathrm{Cd}$ showed a higher contamination level in all four sampling lines. The $I_{\text {geo }}$ values $\left(1<I_{\text {geo }}<2\right)$ of Cd accounted for $67 \%$ of all $I_{\text {geo }}$ values and occurred at moderate to strong levels $\left(2.01<I_{\text {geo }}<2.86\right)$. The higher concentration of $\mathrm{Cd}$ might be related to the sediment movements resulting from the implementation of controls over the sediment flow of Xiaolangdi Reservoir (Bai et al. 2012). Copper, Ni and Zn showed an elevated trend in lines $\mathrm{A}$ and $\mathrm{C}$ corresponding to the region along the Yellow River and the low-salinity area, indicating that they were more likely to be influenced by suspended sediments and artificial aging. No significant differences in $I_{\text {geo }}$ values were observed for lines B and D. The low $I_{\text {geo }}$ values in the four sampling lines indicated that the Yellow River Delta in general was not severely polluted by heavy metals.

When compared with heavy metal concentrations in other river delta regions worldwide (Table 3 ) the concentrations of $\mathrm{Cu}, \mathrm{Pb}$, and $\mathrm{Zn}$ in agricultural soils of the Yellow River Delta were relatively low. Petroleum exploration is prevalent in the Niger Delta, resulting in multiple incidences of oil spills, waste discharges, gas flaring, and chemical disposal into the environment, thus increasing soil contamination (Olawoyin et al. 2012). Although oil production has been carried out in the Yellow River Delta, the region has not appeared to be heavily contaminated by metals. The concentrations of $\mathrm{Cu}$, $\mathrm{Ni}, \mathrm{Pb}$, and $\mathrm{Zn}$ were much lower than that in other two Chinese river deltas (Yangtze River Delta and Pearl River Delta). The relatively high $\mathrm{Cd}$ concentrations might be 


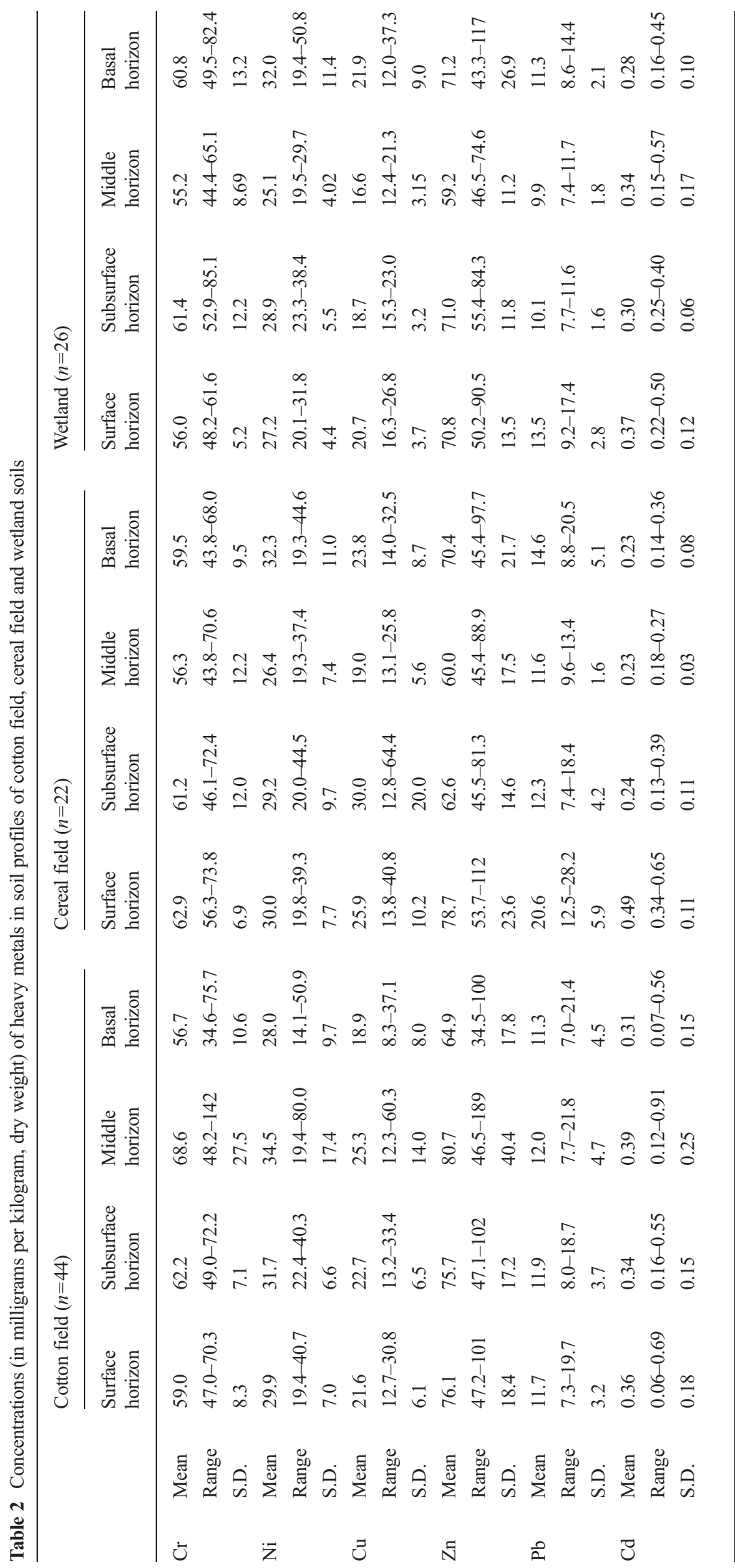


Fig. 2 Box and whisker plots of the geoaccumulation indices for heavy metals in the Yellow River Delta. The boxes extend from the 25 th to the 75 th percentile with a black line at the population median; the whiskers delimit the non-outlier ranges
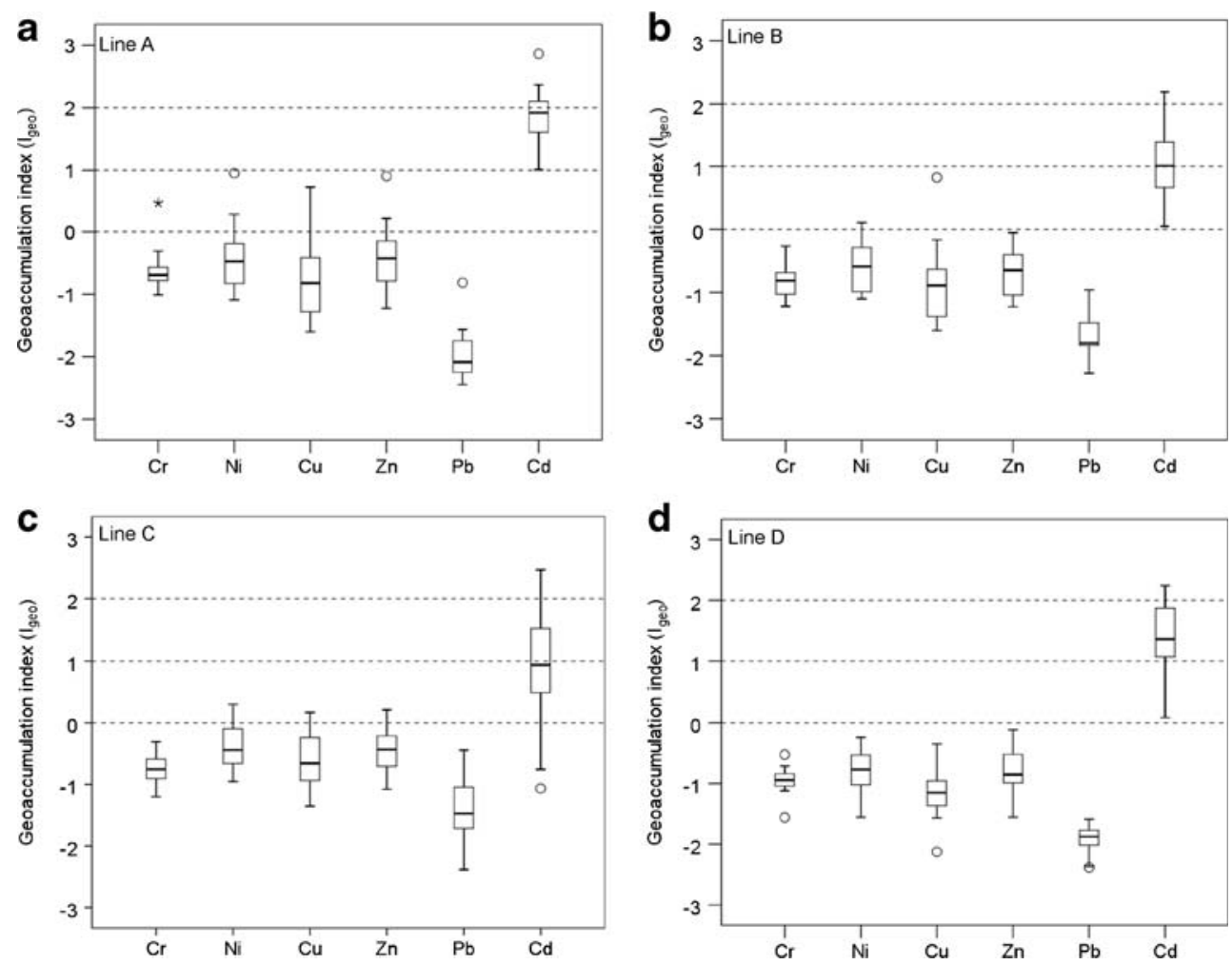

attributed to the alkaline conditions which facilitate the immobilization of metals as carbonate or hydroxide precipitates (Khaokaew et al. 2011). The extent of metal pollution in the surface soils was also assessed by comparing to the soil quality guidelines and the background values of Shandong Province (Table 3). The mean concentration of each heavy metal in the topsoil was lower than the Chinese guideline values. Only $1.1 \% \mathrm{Ni}$ concentrations $\left(80.0 \mathrm{mg} \mathrm{kg}^{-1}\right)$ and
$5.4 \% \mathrm{Cd}$ concentrations $\left(0.62-0.91 \mathrm{mg} \mathrm{kg}^{-1}\right)$ slightly or moderately exceeded their corresponding soil quality guideline values of China. The maximum $\mathrm{Cd}$ concentration of the soils was higher than the corresponding guideline value of China. In addition, the mean concentration of Cd was up to 5.6 times of the background values of eastern Shandong Province and this might be related to the sediment inputs of the Yellow River due to weak anthropogenic influence in the area.

Table 3 Comparison of heavy metal concentrations in agricultural soils (surface horizon) of different river deltas and guideline and background values (in milligrams per kilogram, dry weight)

\begin{tabular}{|c|c|c|c|c|c|c|c|}
\hline River delta, guideline and background value & $\mathrm{Cr}$ & $\mathrm{Ni}$ & $\mathrm{Cu}$ & $\mathrm{Zn}$ & $\mathrm{Pb}$ & $\mathrm{Cd}$ & Reference \\
\hline Yellow River Delta, Dongying, China (mean) & 59.10 & 29.13 & 22.36 & 75.21 & 14.29 & 0.39 & This study \\
\hline Pearl River Estuary, Wanqingsha, China (mean) & 104.68 & 48.14 & 51.52 & 127.41 & 32.23 & 1.18 & Bai et al. (2011a) \\
\hline Yangtze River Delta, Changshu, China (mean) & 53.4 & N/A & 30.5 & 90.1 & 44.5 & 0.168 & Hang et al. (2009) \\
\hline Niger Delta, Nigeria (median) & 13.22 & 42.71 & 28.29 & 58.26 & 895.0 & 1.307 & Olawoyin et al. (2012) \\
\hline Nile Delta, Burrullus lagoon, Egypt (mean) & N/A & 88.94 & 48.05 & 96.54 & 8.22 & 0.086 & Chen et al. (2010) \\
\hline Mississippi River Delta, New Orleans, USA (median) & 1.9 & 9.1 & 17.6 & 147 & 174 & 2.1 & Mielke et al. (2001) \\
\hline Red River Delta, Vietnam (mean) & 88.2 & N/A & 45.3 & 108 & 52.1 & 0.17 & Phuong et al. (2010) \\
\hline Soil quality guidelines of $\mathrm{China}^{\mathrm{a}}$ & 250 & 60 & 100 & 300 & 350 & 0.6 & SEPA (1995) \\
\hline Background values of Shandong ${ }^{\mathrm{b}}$ & 68.0 & 27.6 & 24.3 & 67.5 & 25.6 & 0.084 & CNEMC (1990) \\
\hline Background values of eastern Shandong ${ }^{c}$ & 57.9 & 26.1 & 18.0 & 52.9 & 23.3 & 0.070 & Dai et al. (2011) \\
\hline
\end{tabular}

$N / A$ not available

${ }^{\mathrm{a}} \mathrm{pH}>7.5$, dryland

${ }^{\mathrm{b}}$ Mean values of heavy metals in surface and basal soil horizon

${ }^{\mathrm{c}}$ Values of heavy metals in basal soil horizon 
Fig. 3 Distribution patterns of elements in vertical directions in the soils from two typical profiles: a distribution patterns of heavy metals, $\mathbf{b}$ digital photographs of typical soil profiles; the characteristic soil horizons are indicated by arrows
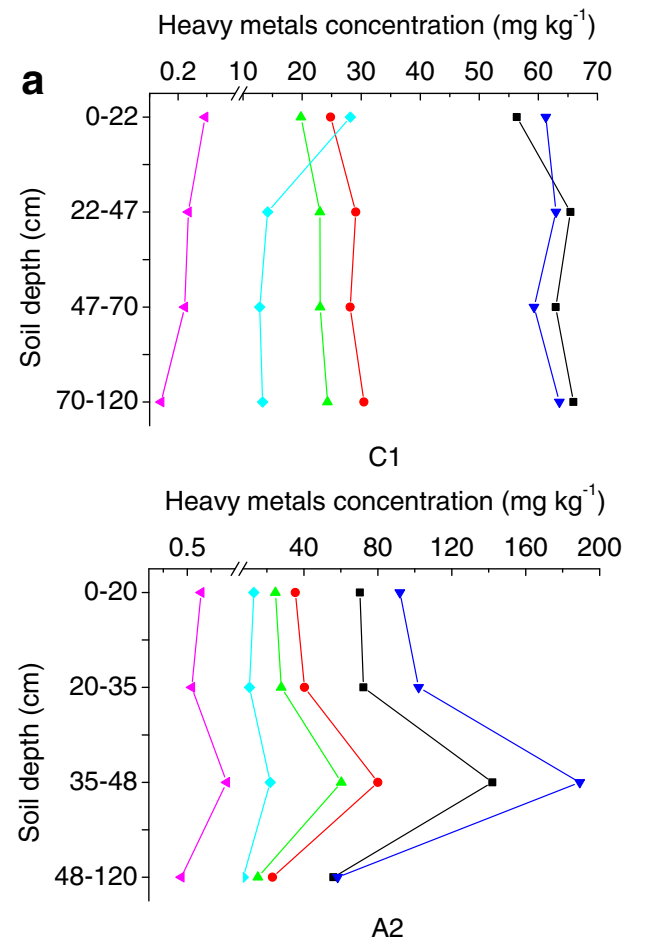

b

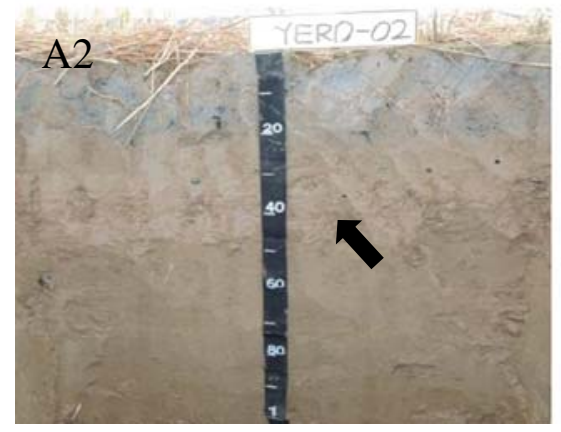

Heavy metals concentration $\left(\mathrm{mg} \mathrm{kg}^{-1}\right)$

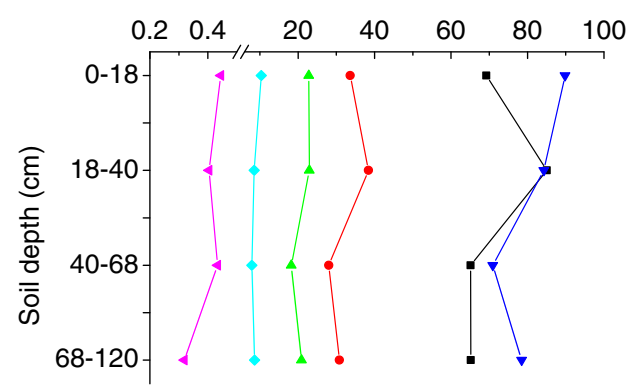

B2

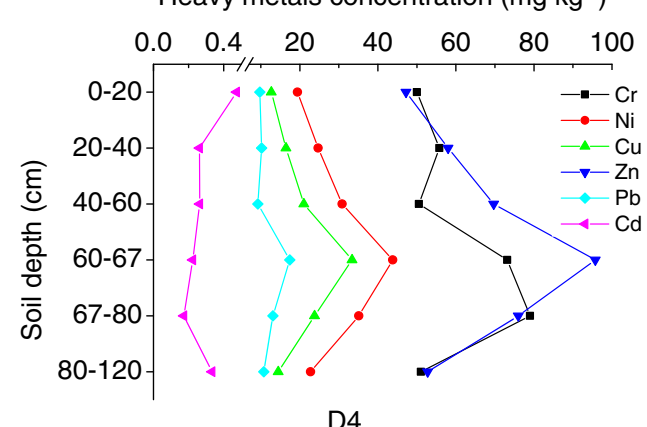

D4

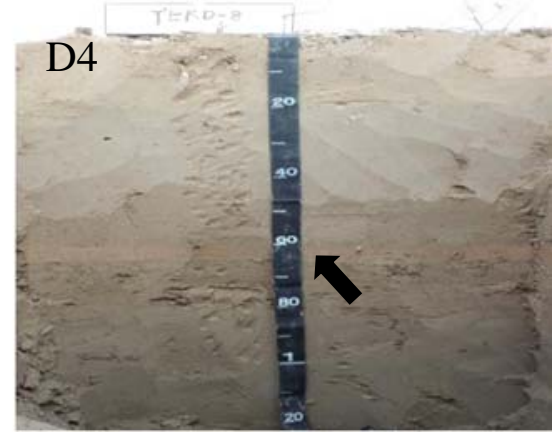

3.3 Depth distribution of heavy metals in typical soil profiles

Two typical soil profiles were selected to investigate the depth distribution of heavy metals throughout the soil profile (Fig. 3). The fluvo-aquic soils represent a widespread soil type in the Yellow River Delta. The texture of soils at sites $\mathrm{C} 1$ and B2 was sandy and that of the subsoil at A2 and D4 was clayey. The concentrations of heavy metals at $\mathrm{C} 1$ and B2 were not significantly different throughout the profile. However, a sharp increase of the heavy metals concentrations occurred at

Table 4 Oxalate and DCB extracted Fe and heavy metal concentrations in soil horizons

\begin{tabular}{|c|c|c|c|c|c|c|c|c|c|c|c|c|c|c|}
\hline \multirow[t]{2}{*}{ Site } & \multirow{2}{*}{$\begin{array}{l}\text { Depth } \\
(\mathrm{cm})\end{array}$} & \multirow{2}{*}{$\begin{array}{l}\mathrm{Fe}_{\text {total }} \\
\left(\mathrm{g} \cdot \mathrm{kg}^{-1}\right)\end{array}$} & \multirow{2}{*}{$\begin{array}{l}\mathrm{Fe}_{\mathrm{DCB}} \\
\left(\mathrm{g} \cdot \mathrm{kg}^{-1}\right)\end{array}$} & \multirow{2}{*}{$\begin{array}{l}\mathrm{Fe}_{\text {oxalate }} \\
\left(\mathrm{g} \cdot \mathrm{kg}^{-1}\right)\end{array}$} & \multicolumn{5}{|c|}{ DCB-extracted metals $\left(\mathrm{mg} \cdot \mathrm{kg}^{-1}\right)$} & \multicolumn{5}{|c|}{ Oxalate-extracted metals $\left(\mathrm{mg} \cdot \mathrm{kg}^{-1}\right)$} \\
\hline & & & & & $\mathrm{Cr}$ & $\mathrm{Ni}$ & $\mathrm{Cu}$ & $\mathrm{Zn}$ & $\mathrm{Pb}$ & $\mathrm{Cr}$ & $\mathrm{Ni}$ & $\mathrm{Cu}$ & $\mathrm{Zn}$ & $\mathrm{Pb}$ \\
\hline \multirow[t]{3}{*}{ A2 } & $0-20$ & 29.3 & 6.12 & 0.89 & 12.3 & 7.1 & 4.3 & 25.2 & 13.9 & 4.1 & 3.5 & 5.5 & 14.6 & 5.63 \\
\hline & $35-48$ & 63.8 & 10.10 & 0.95 & 18.9 & 14.3 & 5.9 & 51.5 & 18.4 & 5.2 & 4.4 & 6.8 & 10.5 & 5.73 \\
\hline & $48-120$ & 21.4 & 4.99 & 0.16 & 10.5 & 7.9 & 3.6 & 27.3 & 9.0 & 4.1 & 2.9 & 3.3 & 15.9 & 5.96 \\
\hline \multirow[t]{3}{*}{ D4 } & $0-20$ & 16.8 & 4.19 & 0.31 & 11.0 & 6.9 & 4.0 & 29.2 & 11.8 & 8.0 & 2.4 & 3.2 & 12.2 & 5.92 \\
\hline & $60-67$ & 35.8 & 12.63 & 0.82 & 19.0 & 15.0 & 6.7 & 39.2 & 22.3 & 4.3 & 4.3 & 6.4 & 12.4 & 5.61 \\
\hline & $80-120$ & 21.2 & 4.57 & 0.19 & 10.9 & 7.2 & 3.9 & 22.2 & 8.3 & 5.7 & 2.8 & 3.1 & 12.8 & 6.65 \\
\hline
\end{tabular}

Characteristic soil horizons are in italics 
Table 5 The major mineral phases in the soil samples

\begin{tabular}{clllllll} 
Site & $\begin{array}{l}\text { Depth } \\
(\mathrm{cm})\end{array}$ & \multicolumn{6}{l}{ Relative proportions of soil minerals (\%) } \\
\cline { 3 - 7 } & & Smectite & Illite & Kaolinite & Chlorite & Quartz & Feldspar \\
\hline A2 & $0-20$ & 2 & 11 & 2 & 7 & 22 & 29 \\
& $35-48$ & 9 & 20 & 12 & 18 & 13 & 6 \\
D4 & $0-20$ & - & 8 & - & 4 & 37 & 31 \\
& $60-67$ & 8 & 22 & 10 & 20 & 12 & 6 \\
$\begin{array}{c}\text { Suspended } \\
\text { particles }\end{array}$ & 15 & 24 & 9 & 4 & 19 & 17 \\
\hline
\end{tabular}

Characteristic soil horizons are in italics

${ }^{a}$ Yellow River-suspended particle matters, data from Huang and Zhang (1990)

the depth of 35-48 and 60-67 cm at sites A2 and D4 (Fig. 3a) corresponding to the special pedogenic horizon (Fig. 3b). A significant accumulation of $\mathrm{Fe}$ and $\mathrm{Mn}$ was also observed at site A2 and was shown a positive correlation $(p<0.01)$ with the heavy metals concentrations. To further explain the heavy metal accumulation in the characteristic soil horizon, the iron oxide content and soil mineral composition were compared between the characteristic soil horizon and other pedogenic soil horizons for the sites A2 and D4 (Tables 4 and 5). The concentrations of iron and heavy metals that extracted by DCB and ammonium oxalate solutions in the different soil horizons are given in Table 4. It could be found that DCBextractable $\mathrm{Fe}$ and heavy metal concentrations in the characteristic soil horizons were two to three times higher than that in the surface and deeper horizons. Nevertheless, the accumulation was not obvious for oxalate-extracted heavy metals in the characteristic soil horizons with the exception of $\mathrm{Ni}$ and $\mathrm{Cu}$. Ammonium oxalate is generally used to extract amorphous iron compound while DCB is widely used to extract both the poorly ordered and the crystalline Fe-oxide fraction, including ferrihydrite, goethite, and hematite (Claff et al. 2010). Therefore, the results of extraction suggested that crystalline iron oxides might be an important soil parameter in retaining the heavy metals in the characteristic soil horizon. The ferrihydrite, for example, was commonly found with specific surface areas on the order of $50-200 \mathrm{~m}^{2} \mathrm{~g}^{-1}$ (Waychunas et al. 2005), which might provide relatively high reactivity sites to bind the trace metals. Iron oxide minerals can also act as sinks for trace elements via co-precipitation during $\mathrm{Fe}$ (II) oxidation in the biogeochemical iron cycling process due to their tendency to nucleate and grow on the surfaces of other mineral phases (Frierdich et al. 2012; Waychunas et al. 2005). XRD results confirmed that clay silicates were the main minerals in the characteristic soil horizons compared with surface soil horizons which dominated by primary minerals (Table 5). It should be noted that 2:1 layer silicates, like illite and smectite were the predominant clay minerals in the characteristic soil horizons, followed by 2:1:1 (chlorite) and 1:1 (kaolinite) layer silicates. The high cation exchange capacity and specific surface areas of layer silicates (e.g., illite are in the range of $20-50 \mathrm{cmol}_{\mathrm{c}} \mathrm{kg}^{-1}$ and

Table 6 Principal component (PC) loading of heavy metals and soil properties

\begin{tabular}{|c|c|c|c|c|c|c|c|c|c|c|c|}
\hline \multirow[t]{3}{*}{ Variable } & \multicolumn{5}{|c|}{ Wetland soil $(n=12)$} & \multicolumn{6}{|c|}{ Agricultural soil $(n=30)$} \\
\hline & \multicolumn{3}{|c|}{ Surface horizon $^{\mathrm{a}}$} & \multicolumn{2}{|c|}{ Basal horizon $^{\mathrm{b}}$} & \multicolumn{3}{|c|}{ Surface horizon $^{\mathrm{c}}$} & \multicolumn{3}{|c|}{ Basal horizon $^{\mathrm{d}}$} \\
\hline & $\mathrm{PC} 1$ & $\mathrm{PC} 2$ & PC3 & $\mathrm{PC} 1$ & $\mathrm{PC} 2$ & PC1 & $\mathrm{PC} 2$ & PC3 & $\mathrm{PC} 1$ & $\mathrm{PC} 2$ & PC3 \\
\hline $\mathrm{Cr}$ & 0.76 & 0.54 & -0.17 & 0.89 & 0.40 & 0.70 & 0.44 & 0.37 & 0.90 & -0.05 & -0.26 \\
\hline $\mathrm{Ni}$ & 0.93 & -0.35 & -0.08 & 0.97 & -0.03 & 0.93 & 0.28 & 0.07 & 0.93 & 0.31 & 0.08 \\
\hline $\mathrm{Cu}$ & 0.90 & 0.02 & 0.29 & 0.98 & -0.11 & 0.78 & 0.61 & 0.29 & 0.88 & 0.40 & -0.03 \\
\hline $\mathrm{Zn}$ & 0.86 & -0.03 & 0.49 & 0.98 & 0.11 & 0.80 & 0.40 & 0.41 & 0.97 & 0.09 & 0.17 \\
\hline $\mathrm{Pb}$ & -0.37 & -0.54 & 0.64 & 0.76 & -0.73 & 0.04 & 0.83 & -0.36 & 0.44 & 0.83 & -0.05 \\
\hline $\mathrm{Cd}$ & -0.18 & 0.94 & 0.09 & 0.17 & 0.91 & 0.19 & -0.05 & 0.95 & -0.14 & -0.78 & 0.54 \\
\hline $\mathrm{Fe}$ & 0.99 & 0.08 & 0.08 & 0.97 & 0.23 & 0.89 & 0.31 & 0.10 & 0.92 & 0.07 & -0.25 \\
\hline $\mathrm{Al}$ & 0.79 & -0.37 & 0.41 & 0.95 & -0.26 & 0.76 & 0.02 & 0.15 & 0.87 & 0.26 & 0.18 \\
\hline SOM & 0.37 & -0.02 & 0.92 & 0.13 & -0.03 & 0.29 & 0.83 & 0.03 & 0.43 & 0.26 & -0.74 \\
\hline Clay & -0.23 & 0.90 & -0.25 & 0.19 & 0.87 & 0.12 & 0.74 & 0.61 & 0.01 & 0.77 & 0.07 \\
\hline $\mathrm{CaCO}_{3}$ & 0.96 & -0.26 & -0.04 & 0.98 & 0.18 & 0.79 & -0.42 & -0.34 & 0.25 & 0.01 & 0.89 \\
\hline
\end{tabular}

Positive loadings of correlation coefficients that above 0.50 are in italics

${ }^{\text {a }}$ Three factors (eigenvalues $>1$ ) to explain the $93.26 \%$ of the total variance

${ }^{\mathrm{b}}$ Two factors (eigenvalues $>2$ ) to explain the $86.54 \%$ of the total variance

${ }^{\mathrm{c}}$ Three factors (eigenvalues $>1$ ) to explain the $84.96 \%$ of the total variance

${ }^{\mathrm{d}}$ Three factors (eigenvalues $>1$ ) to explain the $84.96 \%$ of the total variance 
50-200 $\mathrm{m}^{2} \mathrm{~g}^{-1}$, respectively) are considered to be important adsorptive sites to bind heavy metals (Kahle et al. 2002; Zachara et al. 1992). Moreover, the higher amount of primary minerals, like quartz and feldspar in surface horizon than characteristic horizon, represented a more coarse-textured soil, which could facilitate the leaching of heavy metals downward resulting in the deposition of heavy metals in the characteristic horizon ( $\mathrm{Li}$ et al. 2009). Thus, the accumulation of most heavy metals in the characteristic soil horizons showed in Fig. 3a could be preliminarily attributed to higher amount of iron oxide and clay minerals in characteristic soil horizons than other soil horizons in the soil profiles.

The Yellow River Delta was formed by alluvial and siltation processes. Due to substantial soil erosion in the middle reaches of the Loess Plateau region, large amounts of sand and soil transported by the Yellow River were deposited in the delta. The sites where characteristic red color interlayer soil was observed are located mainly in the reclaimed land which has been created by rapid sediment deposition over the past 160 years (Yu et al. 2011). The dominant soil types of the Loess Plateau are loessal mein soil, red loessal soil, aeolian sand soil, and warp soil (Wang et al. 2009). The interlayer may have been formed by deposition of red loessal soil from the Loess Plateau. In addition, the similar mineral compositions (e.g., illite, kaolinite, and quartz) between characteristic interlayer soils and Yellow River suspended particulate matters also pointed to the deposition of suspended sediments in characteristic interlayer due to water erosion of the soil in the Loess Plateau and hydrodynamic sorting of suspended matters in the Yellow River (Table 5).

\subsection{Source attribution}

PCA was used to identify associations among 11 geochemical variables in the soil from two types of land use and to corroborate the metal provenance (Facchinelli et al. 2001). The results of PCA applied to the entire dataset are listed in Table 6 . The PC1 (lithogenic inputs) had significantly positive loadings for $\mathrm{Al}, \mathrm{Cr}, \mathrm{Cu}, \mathrm{Fe}, \mathrm{Ni}$, and $\mathrm{Zn}$ regardless of land use, the assemblage of metals that standard for the detritic mineral matrix, or positive loadings for $\mathrm{CaCO}_{3}$ in the soil that represent the weathering of parent materials due to the strongly calcareous nature of the soils in the study area. However, not all heavy metals could be distributed on one component. For example, $\mathrm{Cu}$ was associated mainly with $\mathrm{PC} 1$ in the surface horizon of agricultural soils and partially with PC2. This suggested that all of the metals might be controlled by additional factors. As for the PC2 which contained $\mathrm{Cd}$ and clay in both surface and basal horizons of the wetland soil, this factor implied allochthonous inputs of $\mathrm{Cd}$ from the fine-grained sediments of the Yellow River deposited in the estuary area. Moreover, $\mathrm{Pb}$ was not only strongly associated with $\mathrm{PC} 3$ in the surface horizon but also associated with $\mathrm{PC} 1$ in the basal horizon of the wetland, indicating biogeochemical cycling due to plant uptake of $\mathrm{Pb}$ from surface soils or lead-enriched atmospheric fallout through root or foliage (Uzu et al. 2010). Khoo and Tan (2006) reported that conventional onshore crude oil extraction come from venting and flaring operations, and volatilization caused the air emissions of toxic heavy metals such as arsenic, cadmium, lead, and mercury. In the agricultural soil, $\mathrm{Pb}$ was grouped into the $\mathrm{PC} 2$, which could be associated with organic-clay complex during long-term anthropogenic mellowing; and it may leach downward with clay particles. Cadmium was grouped into the PC3 in the agricultural soil; the slight positive loading for clay in the surface horizon may be attributed to the anthropogenic disturbance change in the storage form of $\mathrm{Cd}$ in the soil with comparison of wetland soil. In the basal horizon of agricultural soil, the PC3 included positive loadings for $\mathrm{Cd}$ and $\mathrm{CaCO}_{3}$, which may be partly related to the weathering of calcium-based minerals and the precipitation of $\mathrm{Cd}$ carbonate minerals (Holm et al. 1996).
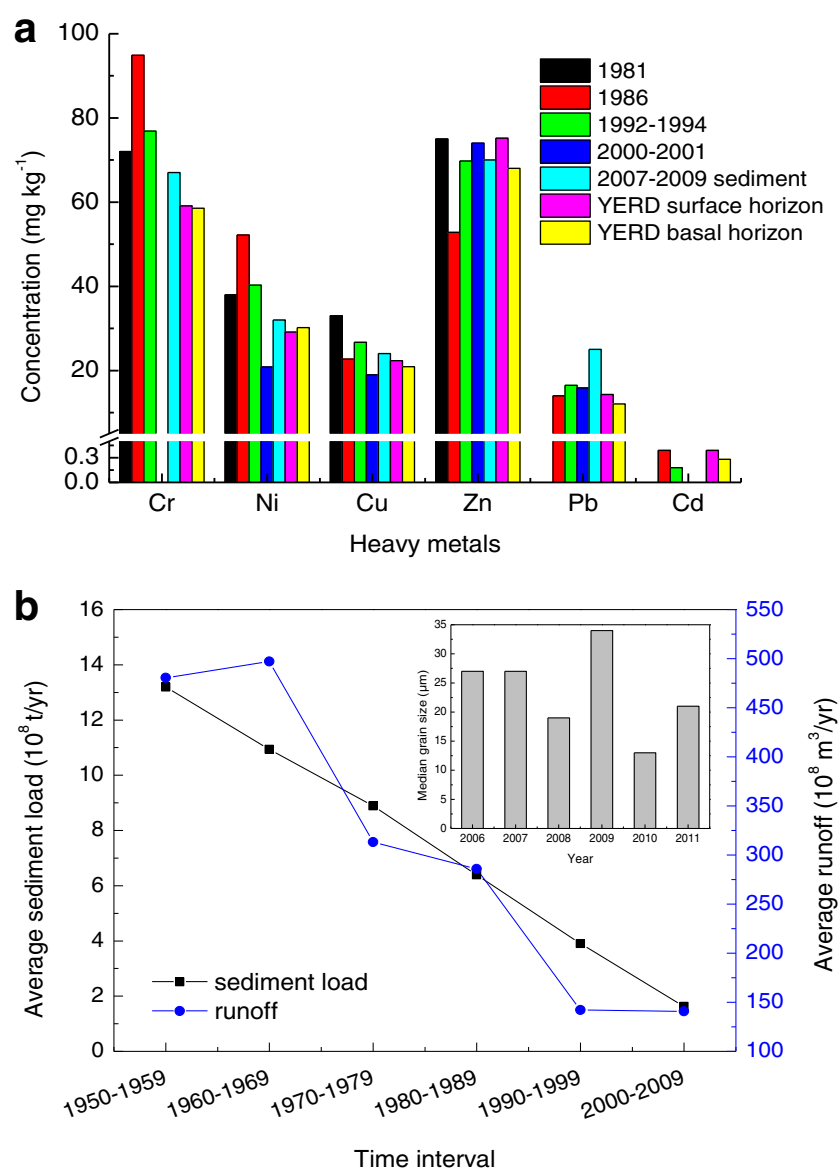

Fig. 4 a Comparisons of metal concentrations in suspended particle matters from the Yellow River (1981-2001), in sediments off the mouth of the Yellow River (2007-2009) and in the soils of the Yellow River Delta (2012); b average annual sediment loads, runoff and median grain size of suspended sediment (inset) at Lijin station. Data for 1981, 1986, 1992-1994, 2000-2001, and 2007-2009 are from Li et al. (1984), Huang et al. (1992), Zhang and Liu (2002), Qiao et al. (2007), and Qiao et al. (2013), respectively 
The annual sediment load from the Yellow River was approximately $1.2 \times 10^{9}$ tons in the delta area, of which $80 \%$ was deposited in the delta and coastal zone and other $20 \%$ transported to the ocean (Chen et al. 2007). The large amount of suspended sediment is a major carrier of elements from the river to the ocean and has an important influence on ecological systems in the delta (Qiao et al. 2007). Figure 4 shows heavy metal concentrations in the suspended particles of the Yellow River, in sediments off the mouth of the Yellow River, and in the soils of the Yellow River Delta; the changes in sediment load of the Yellow River at Lijin station which is located $100 \mathrm{~km}$ upstream from the river mouth is the last hydrological observation station before the river discharges into the Bohai Sea. Compared with historical data on suspended particles (Fig. 4a), the metal concentrations of the Yellow River Delta soils varied little (e.g., $\mathrm{Cd}, \mathrm{Cu}$, and $\mathrm{Zn}$ ) or decreased slightly (e.g., $\mathrm{Ni}, \mathrm{Cr}$, and $\mathrm{Pb}$ ). According to the soil development process in the area, the basal horizon may be more likely to be influenced by the historical input of sediments. The rapid deposition and high dilution capability of the Yellow River may explain the small variation (Zhou et al. 2013). Sediment loading from the Yellow River at Lijin station has been found declining since the 1950s (Fig. 4b), which might decrease the metal concentrations in the surface horizon together with a leaching by rainwater. However, the variation of metal concentrations between the surface and basal horizons suggested the influence of human activities on the surface soils.

Huang and Zhang (1990) have reported that particulate metals are transported seaward by suspended sediments mainly in the silt fraction. The average grain size of the sediments at Lijin station was $23 \mu \mathrm{m}$ in recent years (Fig. 4b, inset) and varied little compared with that in the past two decades (1987 to $2010,21 \mu \mathrm{m}$ ) or past five decades (1962 to 2010, $19 \mu \mathrm{m}$; Yellow River Conservancy Commission). As a consequence, the similar concentrations of heavy metals in the soils and sediments indicate natural inputs from Yellow River suspended sediments. In addition, most metals in the Yellow River suspended particles were carried in crystalline phases, especially alumino-silicates and Fe-Mn containing minerals, and this also suggests a role for geochemical processes (Huang and Zhang 1990).

\section{Conclusions}

This study investigated heavy metal distribution in soil profiles of the Yellow River Delta. The results showed that although $\mathrm{Cd}$ was present at higher concentrations than the background values of Shandong soils, the $I_{\text {geo }}$ index of $\mathrm{Cd}, \mathrm{Cr}, \mathrm{Cu}$, $\mathrm{Ni}, \mathrm{Pb}$, and $\mathrm{Zn}$ in the soils were mostly $<2$ indicating little contamination of these metals in the study area. However, accumulation of heavy metals was identified in the middle horizon of the soil profiles which were located mainly in reclaimed land created by rapid sediment deposition over the past 160 years. Thus, further studies were necessary to clarify the composition and source of this soil horizon and to understand its effect on the transport of heavy metals in the soil profile. The suspended sediments were suggested to be one of the main sources of heavy metals in the basal soil horizon while the surface soil may be influenced by anthropogenic factors.

Acknowledgments The authors are grateful for the financial support by the National Natural Science Foundation of China (NSFC) (41230858 and 41371313) and the Key Research Program of the Chinese Academy of Sciences (KZZD-EW-14). The authors thank the reviewers for their constructive comments.

\section{References}

Bai JH, Xiao R, Cui BS, Zhang KJ, Wang QG, Liu XH, Gao HF, Huang LB (2011a) Assessment of heavy metal pollution in wetland soils from the young and old reclaimed regions in the Pearl River Estuary, South China. Environ Pollut 159:817-824

Bai JH, Huang LB, Yan DH, Wang QG, Gao HF, Xiao R, Huang C (2011b) Contamination characteristics of heavy metals in wetland soils along a tidal ditch of the Yellow River Estuary, China. Stoch Env Res Risk A 25:671-676

Bai JH, Xiao R, Zhang KJ, Gao HF (2012) Arsenic and heavy metal pollution in wetland soils from tidal freshwater and salt marshes before and after the flow-sediment regulation regime in the Yellow River Delta, China. J Hydrol 450-451:244-253

Cenci RM, Martin JM (2004) Concentration and fate of trace metals in Mekong River Delta. Sci Total Environ 332:167-182

Chen JY, Taniguchi M, Liu GQ, Miyaoka K, Onodera SI, Tokunaga T, Fukushima Y (2007) Nitrate pollution of groundwater in the Yellow River Delta, China. Hydrogeol J 15:1605-1614

Chen ZY, Salem A, Xu Z, Zhang WG (2010) Ecological implications of heavy metal concentrations in the sediments of Burullus Lagoon of Nile Delta, Egypt. Estuar Coast Shelf Sci 86:491-498

China National Environmental Monitoring Center (CNEMC) (1990) Chinese elemental background values for soils. Chinese Environmental Science, Beijing (in Chinese)

Claff SR, Sullivan LA, Burton ED, Bush RT (2010) A sequential extraction procedure for acid sulfate soils: partitioning of iron. Geoderma 155:224-230

Cui BS, Zhang QJ, Zhang KJ, Liu XH, Zhang HG (2011) Analyzing trophic transfer of heavy metals for food webs in the newly-formed wetlands of the Yellow River Delta, China. Environ Pollut 159: $1297-1306$

Dai JR, Pang XG, Yu C, Wang CL, Wang ZH, Hu XP (2011) Geochemical baselines and background values and element enrichment characteristics in soils in eastern Shandong Province. Geochimica 40:577-587 (in Chinese)

Facchinelli A, Sacchi E, Mallen L (2001) Multivariate statistical and GISbased approach to identify heavy metal sources in soils. Environ Pollut 114:313-324

Fang HL, Liu GH, Kearney M (2005) Georelational analysis of soil type, soil salt content, landform, and land use in the Yellow River Delta, China. Environ Manage 35:72-83

Förstner U, Heise S, Schwartz R, Westrich B, Ahlf W (2004) Historical contaminated sediments and soils at the river basin scale. Examples from the Elbe river catchment area. J Soils Sediments 4:247-260

Frierdich AJ, Scherer MM, Bachman JE, Engelhard MH, Rapponotti BW, Catalano JG (2012) Inhibition of trace element release during 
$\mathrm{Fe}(\mathrm{II})$-activated recrystallization of Al-, Cr-, and Sn-substituted goethite and hematite. Environ Sci Technol 46:10031-10039

Hang XS, Wang HY, Zhou JM, Ma CL, Du CW, Chen XQ (2009) Risk assessment of potentially toxic element pollution in soils and rice (Oryza sativa) in a typical area of the Yangtze River Delta. Environ Pollut 157:2542-2549

Holm PE, Andersen BBH, Christensen TH (1996) Cadmium solubility in aerobic soils. Soil Sci Soc Am J 60:775-780

Huang WW, Zhang J (1990) Effect of particle size on transition metal concentrations in the Changiiang (Yangtze River) and the Huanghe (Yellow River), China. Sci Total Environ 94:187-207

Huang WW, Zhang J, Zhou ZH (1992) Particulate element inventory of the Huanghe (Yellow River): a large, high-turbidity river. Geochim Cosmochim Acta 56:3669-3680

Ip CCM, Li X, Zhang G, Wai OWH, Li Y (2007) Trace metal distribution in sediments of the Pearl River Estuary and the surrounding coastal area, South China. Environ Pollut 147:311-323

Kahle M, Kleber M, Jahn R (2002) Predicting carbon content in illitic clay fractions from surface area, cation exchange capacity and dithionite-extractable iron. Eur J Soil Sci 53:639-644

Khaokaew S, Chaney RL, Landrot G, Vogel MG, Sparks DL (2011) Speciation and release kinetics of cadmium in an alkaline paddy soil under various flooding periods and draining conditions. Environ Sci Technol 45:4249-4255

Khoo HH, Tan RBH (2006) Environmental impact evaluation of conventional fossil fuel production (oil and natural gas) and enhanced resource recovery with potential $\mathrm{CO}_{2}$ sequestration. Energ Fuel 20:1914-1924

Laing GD, Rinklebe J, Vandecasteele B, Meers E, Tack FMG (2009) Trace metal behaviour in estuarine and riverine floodplain soils and sediments: a review. Sci Total Environ 407:3972-3985

Li YH, Teraoka H, Yang TS, Chen JS (1984) The elemental composition of suspended particles from the Yellow and Yangtze Rivers. Geochim Cosmochim Acta 48:1561-1564

Li JL, He M, Han W, Gu YF (2009) Availability and mobility of heavy metal fractions related to the characteristics of the coastal soils developed from alluvial deposits. Environ Monit Assess 158:459469

Lu RK (1999) Soil and agricultural chemical analysis methods. Chinese Agricultural Science and Technology, Beijing

Mielke HW, Wang G, Gonzales CR, Le B, Quach VN, Mielke PW (2001) $\mathrm{PAH}$ and metal mixtures in New Orleans soils and sediments. Sci Total Environ 281:217-227

Müller G (1969) Index of geoaccumulation in sediments of the Rhine River. Geojournal 2:108-118

Olawoyin T, Oyewole SA, Grayson RL (2012) Potential risk effect from elevated levels of soil heavy metals on human health in the Niger delta. Ecotoxicol Environ Saf 85:120-130
Phuong NM, Kang Y, Sakurai K, Iwasaki K, Kien CN, Noi NV, Son LT (2010) Levels and chemical forms of heavy metals in soils from Red River Delta, Vietnam. Water Air Soil Pollut 207:319-332

Qiao SQ, Yang ZS, Pan YJ, Guo ZG (2007) Metals in suspended sediments from the Changjiang (Yangtze River) and Huanghe (Yellow River) to the sea, and their comparison. Estuar Coast Shelf Sci 74:539-548

Qiao SQ, Shi XF, Gao JJ, Liu YG, Yang G, Zhu AM, Wang KS (2013) The distribution and variation of elements in sediments off the Huanghe (Yellow) River mouth. Chin J Oceanol Limnol 31:876-885

State Environmental Protection Administration (SEPA) (1995) Environmental quality standard for soils. State Environmental Protection Administration, China. GB15618-1995 (in Chinese)

Tessier A, Campbell PGC (1987) Partitioning of trace metals in sediments: relationships with bioavailability. Hydrobiologia 149:43-52

Uzu G, Sobanska S, Sarret G, Muñoz M, Dumat C (2010) Foliar lead uptake by lettuce exposed to atmospheric fallouts. Environ Sci Technol 44:1036-1042

Wang YQ, Zhang XC, Huang CQ (2009) Spatial variability of soil total nitrogen and soil total phosphorus under different land uses in a small watershed on the Loess Plateau, China. Geoderma 150:141-149

Waychunas GA, Kim CS, Banfield JF (2005) Nanoparticulate iron oxide minerals in soils and sediments: unique properties and contaminant scavenging mechanisms. J Nanoparticle Res 7:409-433

Yellow River Conservancy Commission (2006-2011) Bulletin of Yellow River sediment. http://www.yellowriver.gov.cn/nishagonggao (in Chinese)

Yu J, Fu Y, Li Y, Han G, Wang Y, Zhou D, Sun W, Gao Y, Meixner FX (2011) Effects of water discharge and sediment load on evolution of modern Yellow River Dlta, China, over the period from 1976 to 2009. Biogeosciences 8:2427-2435

Yue TX, Liu JY, Jøgensen SE, Ye QH (2003) Landscape change detection of the newly created wetland in Yellow River Delta. Ecol Model 164:21-31

Zachara JM, Smith SC, Resch CT, Cowan CE (1992) Cadmium sorption to soil separates containing layer silicates and iron and aluminum oxides. Soil Sci Soc Am J 56:1074-1084

Zhang J, Liu CL (2002) Riverine composition and estuarine geochemistry of particulate metals in China - weathering features, anthropogenic impact and chemical fluxes. Estuar Coast Shelf Sci 54:1051-1070

Zhang L, Ye X, Feng H, Jing Y, Ouyang T, Yu X, Liang R, Gao C, Chen W (2007) Heavy metal contamination in western Xiamen Bay sediments and its vicinity, China. Mar Pollut Bull 54:974-982

Zhou GH, Sun BB, Zeng DM, Wei HL, Liu ZY, Zhang BM (2013) Vertical distribution of trace elements in the sediment cores from major rivers in east China and its implication on geochemical background and anthropogenic effects. J Geochem Explor. doi:10. 1016/j.gexplo.2013.03.007 